\title{
A Dyadic Study of Control in Buyer-Supplier Relationships
}

\author{
Anna Aminoff and Kari Tanskanen \\ Aalto University, School of Science, Department of Industrial Management and Engineering, \\ Espoo, Finland \\ \{anna.aminoff,kari.tanskanen\}aaalto.fi
}

\begin{abstract}
Control of supply chains has been discussed in supply chain literature from various viewpoints. While previous studies have generally examined only buyer's perspectives of control, we expand on such previous research by comparing both the buyer's and supplier's views. In this paper our objective is to analyze why the control is distributed in a certain way in the buyer-supplier relationship, and how does the distribution of control affect the buyer-supplier relationship. We categorize the explanations for the distribution of control. We argue that control in the buyer-supplier relationship might look different from buyer's and suppliers' perspectives. We used a multiple case study methodology with six dyadic buyer-supplier relationships and conducted 43 interviews.
\end{abstract}

Keywords: Control, supply chain management, dyadic buyer-supplier relationship.

\section{Introduction}

Control of supply chains has been discussed in supply chain literature from various viewpoints. While previous studies (for example [1-4]) have examined the control in buyer-supplier relationships, these studies have generally examined only buyer's perspectives of control. This research expands on such previous research by comparing both the buyer's and supplier's views of control. We adapted Heide and John's [2] approach to control. They use a term vertical control, and define it as the buyer's control over supplier's decisions. On the other words, the buyer has control or can decide over processes that would otherwise be part of supplier's domain in basic market transaction, Having the proportional nature of control in the dyadic relationship in mind, we aim at answering following research question: Why is control distributed in a certain way in the buyer-supplier relationship? In this research, we are using multiple case study methodology. We have six dyadic buyer-supplier relationships, two buyer companies and their three suppliers. We conducted totally 43 interviews.

\section{$2 \quad$ Literature Review}

TCA theory is most cited theory related to control and it is an integral part of both the buyer-supplier and channel research traditions (for example [2], [7-8]). According to 
TCA, one means by which a firm can safeguard specific assets in the absence of vertical integration is to acquire vertical control over the exchange partner based on mutual commitment [2], [9-10]. Heide and John [2] see that control is not desirable per se, but it is subject to efficiency considerations and deliberate choice. They also argue that the presence of specific assets only creates an incentive to establish a vertical control and does not in itself endow the firm with the ability to actually structure the relationship in the desired fashion. As decision control is a zero sum phenomenon [11], an increase in decision control by other party necessarily comes at the other's expense, meaning that one party's ability to exercise decision control derives from other party's decision to relinquish it. The control relinquishment can either be voluntary strategic choice and efficiency considerations [2], [11] or based on power. Heide and John [6] argue that suppliers won't transfer decision control to buyer without some insurance that the achieved control will not be abused.

Next we will discuss shortly about power in a relationship. We rely our approach of power to SET, more specifically to Emerson's power-dependence theory [6]. Emerson's lot quoted definition of power is: 'The power of actor A over actor B is the amount of resistance on the part of B which can be potentially overcome by B. [6](p. 32). Power is an attribute of a relationship, not an actor, which means that buying organization in not 'powerful' in general, but only with respect to a particular supplier. Most treatments of power emphasize the critical role of dependence. Emerson formulated relationship between power and dependence: 'the relative dependence between two actors in an exchange relationship determines their relative power [6]. He also provided a general conception of dependence: 'The dependence of actor A upon actor B is (1) directly proportional to A's motivational investment goals mediated by B, and (2) inversely proportional to the availability of those goals outside of the A-B relationship. This means that dependence is determined by two factors; the need for a resource, that other party posses and the availability of alternative sources. Power-dependency theory argues that a firm's investment in specific assets may constrain its ability to acquire vertical control, because the presence of specific assets represents conditions of interfirm dependence [2]. Prior studies have explored the nature of dependence and control in buyer-supplier relationships see for instance [12], [13-15].

Control has bee discussed in the context of supply chain management literature by multiple authors (see e.g., [2], [3-5], [13-14], [16-18]). Many of the studies discuss the different control mechanisms, e.g. [1], [16], [20]. Control mechanisms are structural arrangements deployed to regulate partners' behavior. Two categories of control mechanisms have been distinguished: (1) formal control, which rely primarily (but not exclusively) on explicit contracts and (2) social control (or relational forms), which primarily relies on informal means [16], [21-22]. Most of the previous authors have adopted TCE as underlying paradigm, especially when discussing the antecedents that lead to the adoption of formal control [16]. Formal control mechanisms enhance cooperation and decrease opportunistic behaviors, since explicit contracts detail the roles and responsibilities of the partners, determine the deliverable, and specify the processes necessary to resolve unforeseeable problems [24-25]. Some authors suggest that formal control and social control mechanisms are substitutes 
[22], [26] as others argue that formal and social control mechanisms are complementary [23], [27]. Interfirm trust is a primary foundation for the use of social control [1]. Social control mechanisms usually take the form of joint problem solving, participatory decision making, thorough information exchange, and fulfillment of promises [20].

Our approach to control relies on those of previous authors, but also differs slightly from mainstream discussion. We adapted Heide and John's [2] approach to control. They use a terms vertical control, and define it as the buyer's control over supplier's decisions. On the other words, the buyer has control (or can decide) over processes that would otherwise be part of supplier's domain in basic market transaction, like supplier's production process and manufacturing technology, ongoing design and engineering changes, supplier's level of inventory, selection of supplier's subsuppliers and supplier's quality procedures. Our main interest doesn't lie in the control mechanisms as such, but more what are the antecedents and consequences of control distribution.

\section{Method}

In this study, we adopted multiple case study method. We examined the issue of interest through a dyadic study having the buyer-supplier relationship as the unit of analysis. We explored six relationships, which include two buyer companies and six suppliers. We chose dyadic case study, because case studies allow developing frameworks by using data collected through direct interaction with subjects of interest. In the research design and analysis we follow the principles of Eisenhardt [28], and Yin [29]. We selected our cases based on two principles: theoretical sampling and access to data. We came up with two buyer companies and their three suppliers: one company was from the high-technology industry (OEM, a pseudonym), and another was from the pharmaceutical industry (PharCo, a pseudonym). We had multiple sources of data, which made the data rich; interviews, meetings with company representatives, documents and workshops. Having multiple respondents from different companies and utilizing multiple sources of data (interviews, company documents, and memos) put into practice the principle of data triangulation. Interviews were our main source of data, and we conducted totally 43 interviews, and one interview lasted from $45 \mathrm{~min}$ -2 hours.

The first buyer firm - OEM- is a large high technology equipment provider. All three suppliers selected in our study are also ranked in the top five of their respective industries worldwide. HiTecCo supplies OEM components that are technically demanding and critical for the performance of the end product. ContrMan is one of OEM's largest suppliers and it has several plants located near OEM's markets that create manufacturing capacity. CoCom is an original equipment manufacturer that is widely considered to be the technological leader in its field. PharCo is a European R\&D-based pharmaceuticals and diagnostics company focused on the development of medicinal treatments and diagnostic tests for the global market. It is a relatively small player globally but well positioned within European markets. PacCo is a small local supplier of printed products and services for packages and advertisements. This firm 
has a long and stable relationship with PharCo. MedDev is a globally operated supplier of drug delivery, medical devices, and diagnostic disposables. MedDev became a major supplier for PharCo only a few years ago. BulkMf is a manufacturer of bulk actives for the pharmaceuticals industry. BulkMf is also a fairly new supplier for PharCo and is one of PharCo's first low-cost country suppliers.

\section{$4 \quad$ Results}

According to the advice of Yin [29] we conducted within-case analysis and, subsequently, cross-case analysis. The within and cross-case analyses show that the pattern of control, more specifically how control is distributed and why, is different across the six dyads. Here, we will discuss results of cross case analyses and elaborate findings over the cases. We will first make observations how the control is distributed in relationships. Next, we analyze the control distribution as follows. (1) Why it is distributed in certain way and we categorize these explanations. (2) Why the party is relinquishing the control and, (3) what are the control mechanisms.

Table 1 shows the results of cross case analyses. Overall, in all the dyads, both the buyer and the supplier have influence over the explored processes and none of the processes are decided purely by the buyer or by the supplier. This finding supports the fact that all the sample relationships are collaborative and deep in nature. Also, this means that we can't distinguish relationships as 'buyer controls' or 'supplier controls', but it is more complicated than that. In all but one case (OEM- ContrMan), the supplier has more control than the buyer, or the control is balanced. In all case relationships of PharCo, the control is balanced between buyer and the supplier. In multiple cases, the distribution of control differ between product groups in a relationship. For example, in OEM-BulkMf relationship, the buyer wants to secure the availability of some product groups by deciding the suppliers buffer inventory levels, as in some product groups the supplier may decide. Based on our interviews, the buyers were mostly quite satisfied with how control was distributed and didn't feel they would need more control over suppliers' decisions. Also this reflects the fact that relationships are collaborative in nature. Generally, buyers would like to have more control on selection of supplier's subsuppliers. We explored, that there are incongruencies in all dyads, how the buyer and the supplier see the control is distributed in a relationship. For instance, in PharCo-PacCo relationship, PharCo and PacCo see the control distribution to be totally different in multiple processes. In this relationship, the buyer sets strong unilateral pressure to develop the supply chain. Over the course of the study, PharCo simultaneously placed more competitive pressure on PacCo and developed supply chain processes more effective from its own point of view, which decreased the efficiency of PacCo's operations. This unilateral pressure affects how the supplier sees the control and might create problems to the relationship.

We analyzed the antecedents for the control distribution. The table 1 shows how the control is distributed and why. We mapped different explanations for control distribution in sample relationships, and categorized them as follows: (1) Type of purchasing influences strongly control distribution, and there is often a 'natural' 
distribution of control. In contract manufacturing type of purchasing, for example in the relationship between OEM-ContrMan, the buyer generally has much control, especially over design and engineering changes.

Table 1. Results of cross-case analyses

\begin{tabular}{|c|c|c|c|c|c|c|c|c|c|c|c|c|}
\hline Relationship & \multicolumn{2}{|c|}{ OEM-HiTecCo } & \multicolumn{2}{|c|}{ OEM-CoCom } & \multicolumn{2}{|c|}{ OEM-ContrMa } & \multicolumn{2}{|c|}{ PharCo-PacCq } & \multicolumn{4}{|c|}{ PharCo-MedD $\&$ PharCo-BulkM } \\
\hline The company the answer & Buyer & Supplie & Buyer & Supplie & Buyer & Supplie & Buyer & Supplie & Buyer & Supplie & Buyer & Supplie \\
\hline Power balance & \multicolumn{2}{|c|}{ Balanced } & \multicolumn{2}{|c|}{ Supplier } & \multicolumn{2}{|l|}{ Buyer } & \multicolumn{2}{|l|}{ Buyer } & \multicolumn{2}{|c|}{ Balanced } & \multicolumn{2}{|c|}{ Supplier } \\
\hline Specific assets & Med & High & Med & Med & Low & Med & High & High & Med & Low & Low & Low \\
\hline Perception of trust & High & High & High & High & High & High & High & High & High & High & Moderat & High \\
\hline Average power & \multicolumn{2}{|l|}{ High } & \multicolumn{2}{|l|}{ High } & \multicolumn{2}{|c|}{ Medium } & \multicolumn{2}{|c|}{ Medium } & \multicolumn{2}{|c|}{ Medium } & \multicolumn{2}{|c|}{ Medium } \\
\hline Performance & Good & Good & Med & Med & Good & Med & Good & Med & Med & Med & Med & Low \\
\hline \multirow{5}{*}{$\begin{array}{l}\text { Control distribution 1) 2) } \\
\text { A. Supplier's production } \\
\text { processes and } \\
\text { B. Ongoing design and } \\
\text { engineering changes } \\
\text { C. Supplier's level of } \\
\text { inventory } \\
\text { D. Selection of supplier's } \\
\text { sub suppliers } \\
\text { E. Supplier's quality control } \\
\text { procedures }\end{array}$} & 1.4 & 2.0 & 2.5 & 2.3 & 2.2 & 2.3 & 2.5 & 2.0 & 2.8 & 3.7 & 1.3 & 1.0 \\
\hline & 3.2 & 4.0 & 3.3 & 3.3 & 5.8 & 6.7 & 3.5 & 7.0 & 5.5 & 6.2 & 2.5 & 1.0 \\
\hline & 2.8 & 3.0 & 2.7 & 4.0 & 3.0 & 6.0 & 3.5 & 2.0 & 1.5 & 2.5 & 3.3 & 1.0 \\
\hline & 2.0 & 1.5 & 2.5 & 2.7 & 5.4 & 6.3 & 2.5 & 1.0 & 2.3 & 2.6 & 2.3 & 3.0 \\
\hline & 1.7 & 3.0 & 2.8 & 2.7 & 3.8 & 4.0 & 6.5 & 4.0 & 5.5 & 4.2 & 3.0 & 3.0 \\
\hline Control mechanisms & \multicolumn{2}{|c|}{$\begin{array}{l}\text { Contracts, } \\
\text { standards, } \\
\text { monitoring, } \\
\text { social control } \\
\end{array}$} & \multicolumn{2}{|c|}{$\begin{array}{l}\text { Contracts, } \\
\text { standards, } \\
\text { monitoring, } \\
\text { social control } \\
\end{array}$} & \multicolumn{2}{|c|}{$\begin{array}{l}\text { Contracts, } \\
\text { standards, } \\
\text { monitoring, } \\
\text { social control } \\
\end{array}$} & \multicolumn{2}{|c|}{\begin{tabular}{|l|} 
Contracts, \\
standards, \\
monitoring, \\
social control, \\
supplier \\
development \\
\end{tabular}} & \multicolumn{2}{|c|}{\begin{tabular}{|l} 
Contracts, \\
standards, \\
monitoring, \\
\end{tabular}} & \multicolumn{2}{|c|}{$\begin{array}{l}\text { Contracts, } \\
\text { standards, } \\
\text { monitoring, } \\
\text { supplier } \\
\text { development }\end{array}$} \\
\hline Influence mechanisms: & Trust & & \multicolumn{2}{|c|}{ Trust } & \multicolumn{2}{|c|}{ Power } & \multicolumn{2}{|c|}{ Power } & \multicolumn{2}{|c|}{ Trust } & \multicolumn{2}{|c|}{\begin{tabular}{|l|} 
Power \\
\end{tabular}} \\
\hline \multicolumn{3}{|c|}{ Reasons for control distribution } & & & \multirow{4}{*}{\multicolumn{2}{|c|}{$\begin{array}{l}\text { Type of } \\
\text { purchasing, } \\
\text { Capabilities of } \\
\text { partners } \\
\text { Type of } \\
\text { purchasing, } \\
\text { Capabilities of } \\
\text { the partners } \\
\text { Supply chain } \\
\text { efficiency, } \\
\text { minimize the } \\
\text { effort of the }\end{array}$}} & & & & & & \\
\hline $\begin{array}{l}\text { A. Supplier's production } \\
\text { processes and } \\
\text { manufacturing technology }\end{array}$ & \multicolumn{2}{|c|}{$\begin{array}{l}\text { Capabilities of } \\
\text { partners }\end{array}$} & \multirow{3}{*}{\multicolumn{2}{|c|}{$\begin{array}{l}\text { Capabilities of } \\
\text { partners } \\
\text { Capabilities of } \\
\text { the partners, } \\
\text { Type of } \\
\text { purchasing } \\
\text { Supply chain } \\
\text { efficiency, } \\
\text { minimize the } \\
\text { effort of the }\end{array}$}} & & & $\begin{array}{l}\text { Capabi } \\
\text { partner }\end{array}$ & ties of & $\begin{array}{l}\text { Type } \\
\text { purch } \\
\text { Capak } \\
\text { the pa }\end{array}$ & $\begin{array}{l}\text { ng } \\
\text { ties of } \\
\text { lers }\end{array}$ & $\begin{array}{l}\text { Capabili } \\
\text { partners }\end{array}$ & ties of \\
\hline $\begin{array}{l}\text { B. Ongoing design and } \\
\text { engineering changes }\end{array}$ & $\begin{array}{l}\text { Capabi } \\
\text { partner } \\
\text { of purcl }\end{array}$ & $\begin{array}{l}\text { ites of } \\
\text {, Type } \\
\text { lasing }\end{array}$ & & & & & $\begin{array}{l}\text { Capabi } \\
\text { partner }\end{array}$ & tes of & $\begin{array}{l}\text { Type of } \\
\text { purcha } \\
\text { Capabi } \\
\text { partner }\end{array}$ & $\begin{array}{l}\text { ing, } \\
\text { ities of }\end{array}$ & $\begin{array}{l}\text { Capabili } \\
\text { partners } \\
\text { of purch }\end{array}$ & $\begin{array}{l}\text { ties of } \\
\text { Type } \\
\text { asing, }\end{array}$ \\
\hline $\begin{array}{l}\text { C. Supplier's level of } \\
\text { inventory (raw material, } \\
\text { semi finished and finished } \\
\text { components) }\end{array}$ & $\begin{array}{l}\text { Supply } \\
\text { efficien } \\
\text { minimiz } \\
\text { effort of }\end{array}$ & $\begin{array}{l}\text { chain } \\
\text { ey, } \\
\text { the }\end{array}$ & & & & & $\begin{array}{l}\text { Supply } \\
\text { efficien }\end{array}$ & hain & $\begin{array}{l}\text { Capa } \\
\text { partn }\end{array}$ & ties of & $\begin{array}{l}\text { Supply c } \\
\text { efficienc }\end{array}$ & $\begin{array}{l}\text { chain } \\
y\end{array}$ \\
\hline $\begin{array}{l}\text { D. Selection of supplier's } \\
\text { sub suppliers }\end{array}$ & $\begin{array}{l}\text { Buyer v } \\
\text { influenc } \\
\text { certain }\end{array}$ & $\begin{array}{l}\text { lants to } \\
\text { e to } \\
\text { eeeds }\end{array}$ & $\begin{array}{l}\text { Buyer } \\
\text { influen } \\
\text { certain }\end{array}$ & $\begin{array}{l}\text { lants to } \\
\text { e to } \\
\text { eeeds }\end{array}$ & $\begin{array}{l}\text { Type o } \\
\text { purch } \\
\text { Capab } \\
\text { the pa }\end{array}$ & $\begin{array}{l}\text { ing } \\
\text { ities of } \\
\text { ners }\end{array}$ & $\begin{array}{l}\text { Capabi } \\
\text { partner } \\
\text { wants } t \\
\text { influen } \\
\text { certain }\end{array}$ & $\begin{array}{l}\text { ties of } \\
\text {, Buyer } \\
\text { e to } \\
\text { eeeds }\end{array}$ & $\begin{array}{l}\text { Buyer v } \\
\text { influenc } \\
\text { certain }\end{array}$ & $\begin{array}{l}\text { lants to } \\
\text { e to } \\
\text { needs }\end{array}$ & $\begin{array}{l}\text { Capabili } \\
\text { partners } \\
\text { wants to } \\
\text { influence } \\
\text { certain n }\end{array}$ & $\begin{array}{l}\text { ties of } \\
\text {, Buyer } \\
\text { e to } \\
\text { needs }\end{array}$ \\
\hline $\begin{array}{l}\text { E. Supplier's quality control } \\
\text { procedures }\end{array}$ & $\begin{array}{l}\text { Capabi } \\
\text { partner }\end{array}$ & es of & $\begin{array}{l}\text { Capab } \\
\text { partne }\end{array}$ & es of & $\begin{array}{l}\text { Capab } \\
\text { partne }\end{array}$ & ies of & $\begin{array}{l}\text { Buyer } \\
\text { influen } \\
\text { certain }\end{array}$ & $\begin{array}{l}\text { lants to } \\
\text { e to } \\
\text { eeeds }\end{array}$ & $\begin{array}{l}\text { Buyer } \\
\text { influen } \\
\text { certain }\end{array}$ & $\begin{array}{l}\text { lants to } \\
\text { e to } \\
\text { needs }\end{array}$ & $\begin{array}{l}\text { Buyer w } \\
\text { influence } \\
\text { certain }\end{array}$ & $\begin{array}{l}\text { lants to } \\
\text { e to } \\
\text { eeeds }\end{array}$ \\
\hline
\end{tabular}

1) Vertical control measures the control buyer has achieved over.

2) Scale (1-7): 1= Entirely decided by the supplier, $7=$ entirely decided by the customer.

(2) Capabilities of partners: the partner with best capabilities decides / conducts the process. For instance, in OEM-HitecCo case, supplier mainly decides the production processes, but the buyer makes suggestions if it would like to have new technology. OEM sees that HitecCo has best capabilities in deciding the production process. (3) Buyer wants to influence to specific needs that are important to the buyer. For instance, for OEM, issues related to environment and ethics are important and OEM controls that supplier takes these issues into consideration. Authority requirements belong to this category. For example, authorities require that PharCo must have control over suppliers' quality procedures. (4) Buyer wants to minimize the work and 
gives the control to the supplier, as in the case of consignment stock. As decision control is a zero sum phenomenon [11], an increase in control by other party necessarily comes at the other's expense, meaning that one party's ability to exercise decision control derives from other party's decision to relinquish it. Heide and John [2] argue that suppliers won't transfer decision control to buyer without some insurance that the achieved control will not be abused. We analyzed why supplier (or buyer) relinquished the control to the other party and identified following 'enablers' (see also table 2): (1) Trust, control relinquishment is a strategic choice. Partner relinquishes the control often due to efficiency considerations. When a trust is high in a relationship, one can trust the other party doesn't behave opportunistically. (2) Power, more powerful party can force the other party to relinquish the control. Many of the control mechanism used in our sample relationships are formal ones, written explicitly in contracts. Some mechanisms are related to relational norms, and are close to supplier development, as the buyer helps the supplier to develop processes. For example, PharCo has helped its suppliers to develop production processes. Also, buyer controls the supplier by having requirements for (ISO) standards and via auditing, also supplier's subsuppliers. Buyer might also specify the product that there is only one supplier, although it doesn't specify the 'name' of the supplier. Also, multiple control mechanisms can affect to one process. Many of the previous authors discuss about contracts as control mechanism (see for example, [1], [32], [36], [39]), but other explored mechanisms (helping the supplier to develop, standards) are mentioned more rarely.

\section{Discussion and Conclusion}

For the most part, previous studies have only examined the perspective of the buyer, and this study is one of the first to take a dyadic view. Traditionally, TCE has been adopted as a primary theoretical lens to explore the antecedents of control mechanisms in buyer-supplier cooperation, for example [2], [4], [13-14]. Our study provides empirical evidence that the approach of TCE, in which, control is used to safeguard specific assets, doesn't explain the control distribution in buyer-supplier relationships. Also, some previous authors, for example [23], have criticized TCEs approach to control and argue that transaction cost economics overstates the desirability of either integration or explicit contractual safeguards in exchange settings commonly labeled as hazardous. We found out that control is a complex concept. In most relationships, both buyer and supplier have control over processes, and the distribution of control may vary between product groups. It is not easy to determine, who controls the supply chain. We argue that control in the buyer-supplier relationship might look different from buyer's and suppliers' perspectives. One relevant explanation for these incongruencies in perceptions is the unilateral nature of the relationship, in where the buyer bases its action to the power. We categorized the explanations for control distribution and discussed the impact of power, trust and attractiveness. We argue that in bilateral relationships, trust enables the efficiency considerations of control distribution, and the partner who has best capabilities has the control over processes. 
For business managers this paper gives new insights for managing the control in the supply chain. We note that business managers must consider how the other party sees the control, as there might be mismatches in perceptions. Managers also need to rethink the control in supply chains and analyze the explanations why the control is distributed in the way it is and if it is optimal for the supply chain. Also, we found out that a company can persuade the other party to relinquish the control by three ways unilateral power, award power by being more attractive business partner and/ or trust.

\section{References}

1. Jap, S.D., Ganesan, S.: Control Mechanisms and the Relationship Life Cycle: Implications for Safeguarding Specific Investments and Developing Commitment. Journal of Marketing Research (JMR) 37(5), 227-245 (2000)

2. Heide, J.B., John, G.: Do norms matter in marketing relationships. Journal of Marketing 56, 32-44 (1992)

3. Mol, M.J.: Outsourcing: Design, Process and Performance. Cambridge University Press, UK (2007)

4. Petersen, K.J., Handfield, R.B., Lawson, B., Cousins, P.D.: Buyer Dependency and Relational Capital Formation: The Mediating Effects of Socialization Processes and Supplier Integration. Journal of Supply Chain Management 44, 53-65 (2008)

5. Zhao, X., Huo, B., Flynn, B.B., Yeung, J.H.Y.: The impact of power and rela-tionship commitment on the integration between manufacturers and customers in a supply chain. J. Oper. Manage. 26(5), 368-388 (2008)

6. Emerson, R.M.: Power-Dependence Relations. American Sociological Review 27, 31-41 (1962)

7. Morgan, R.M., Hunt, S.: Relationship-Based Competitive Advantage: The Role of Relationship Marketing in Marketing Strategy. Journal of Business Research 46(11), 281-290 (1999)

8. Morgan, R.M., Hunt, S.D.: The Commitment-Trust Theory of Relationship Marketing. J. Market. 58(7), 20 (1994)

9. Williamson, O.E.: The Economic Institutions of Capitalism; Firms, Markets, Relationalcontracting. Free Press, New York (1985)

10. Powell, W.W.: Hybrid Organizational Arrangements: New Form or Transitional Development? Calif. Manage. Rev. 30, 67-87 (Fall 1987)

11. Grossman, S.J., Hart, O.D.: The Costs and Benefits of Ownership: A Theory of Vertical and Lateral Integration. Journal of Political Economy 94(8), 691-719 (1986)

12. El-Ansary, A., Stern, L.W.: Power Measurement in the Distribution Channel. Journal of Marketing Research (JMR) 9(2), 47-52 (1972)

13. Provan, K.G., Skinner, S.J.: Interorganizational Dependence and Control as Predictors of Opportunism in Dealer-Supplier Relations. Academy of Management Journal 32(3), 202-212 (1989)

14. Frazier, G.L., Gill, J.D., Kale, S.H.: Dealer Dependence Levels and Reciprocal Actions in a Channel of Distribution in a Developing Country. J. Market. 53(1), 50-69 (1989)

15. Buvik, A., Halskau, Ø.: Relationship duration and buyer influence in just-in-time relationships. European Journal of Purchasing \& Supply Management 7(6), 111-119 (2001)

16. Li, Y., Xie, E., Teo, H., Peng, M.W.: Formal control and social control in do-mestic and international buyer-supplier relationships. J. Oper. Manage. 28(7), 333-344 (2010) 
17. Youngdahl, W., Ramaswamy, K., Verma, K.: Exploring new research frontiers in offshoring knowledge and service processes. J. Oper. Manage. 26(3), 135-140 (2008)

18. Narasimhan, R., Nair, A., Griffith, D.A., Arlbjørn, J.S., Bendoly, E.: Lock-in situations in supply chains: A social exchange theoretic study of sourcing arrangements in buyersupplier relationships. J. Oper. Manage. 27(10), 374-389 (2009)

19. Stump, R.L., Heide, J.B.: Controlling Supplier Opportunism in Industrial Relationships. Journal of Marketing Research (JMR) 33(11), 431-441 (1996)

20. Fryxell, G.E., Dooley, R.S., Vryza, M.: After the Ink Dries: the Interaction of Trust and Control in Us-Based International Joint Ventures. Journal of Management Studies 39(9), 865-886 (2002)

21. Dyer, J.H., Chu, W.: The Role of Trustworthiness in Reducing Transaction Costs and Improving Performance: Empirical Evidence from the United States, Japan, and Korea 14(1) (January-February 2003), 57-68 (2003)

22. Dyer, J.H., Singh, H.: The Relational View: Cooperative Strategy and Sources of Interorganizational Competitive Advantage. The Academy of Management Review 23(4), 660-679 (1998)

23. Poppo, L., Zenger, T.: Do Formal Contracts and Relational Governance Function as Substitutes or Complements? Strategic Manage. J. 23(8), 707 (2002)

24. Rindfleisch, A., Heide, J.B.: Transaction cost analysis: Past, present, and future applications. J. Market. 61(10), 30 (1997)

25. Argyres, N., Mayer, K.J.: Contract Design as a Firm Capability: an Integration of Learning and Transaction Cost Perspectives. Academy of Management Review 32(10), 1060-1077 (2007)

26. Uzzi, B.: Social Structure and Competition in Interfirm Networks: The Paradox of Embeddedness. Adm. Sci. Q. 42(3), 35-67 (1997)

27. Mesquita, L.F., Brush, T.H.: Untangling Safeguard and Production Coordination Effects in Long-Term Buyer-Supplier Relationships. Academy of Management Journal 51(8), 785-807 (2008)

28. Eisenhardt, K.M.: Building Theories from Case Study Research. The Academy of Management Review 14, 532-550 (1989)

29. Yin, D.R.K.: Case Study Research: Design and Methods, 4th edn. Sage Publications, Inc. (2009) 